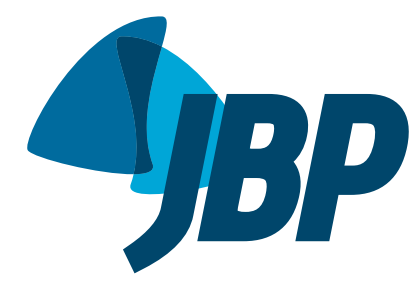

\title{
Functional capacity measurement: reference equations for the Glittre Activities of Daily Living test
}

\author{
Cardine Martins dos Reis ${ }^{1,2, a}$, Manuela Karloh ${ }^{1,3, b}$, \\ Fernanda Rodrigues Fonseca ${ }^{1,2, c}$, Roberta Rodolfo Mazzali Biscaro ${ }^{1,2, d}$, \\ Giovana Zarpellon Mazo ${ }^{4,5, e}$, Anamaria Fleig Mayer ${ }^{1,2,3,5, f}$
}

1. Núcleo de Assistência, Ensino e Pesquisa em Reabilitação Pulmonar, Centro de Ciências da Saúde e do Esporte, Universidade do Estado de Santa Catarina, Florianópolis (SC) Brasil.

2. Programa de Pós-Graduação em Fisioterapia, Centro de Ciências da Saúde e do Esporte, Universidade do Estado de Santa Catarina, Florianópolis (SC) Brasil.

3. Departamento de Fisioterapia, Centro de Ciências da Saúde e do Esporte, Universidade do Estado de Santa Catarina, Florianópolis (SC) Brasil.

4. Departamento de Educação Física, Centro de Ciências da Saúde e do Esporte, Universidade do Estado de Santa Catarina, Florianópolis (SC) Brasil.

5. Programa de Pós-Graduação em Ciências do Movimento Humano, Centro de Ciências da Saúde e do Esporte, Universidade do Estado de Santa Catarina, Florianópolis (SC) Brasil.

a. (iD) http://orcid.org/0000-0003-3992-924X

b. (D) http://orcid.org/0000-0003-2082-2194

\section{ABSTRACT}

Objective: To develop reference equations for the Glittre Activities of Daily Living test (Glittre ADL-test) on the basis of anthropometric and demographic variables in apparently healthy individuals. A secondary objective was to determine the reliability of the equations in a sample of COPD patients. Methods: This was a cross-sectional study including 190 apparently healthy individuals (95 males; median age, 54.5 years [range, 42-65]; median $\mathrm{FEV}_{1}=97 \%$ [range, 91-105.2]; and median FVC = 96\% [range, 88.5-102]) recruited from the general community and 74 COPD patients ( 55 males; mean age, $65 \pm 8$ years; body mass index $[\mathrm{BMI}]=25.9 \pm 4.7 \mathrm{~kg} / \mathrm{m}^{2} ; \mathrm{FEV}_{1}=36.1 \pm 14.1 \%$; and $\mathrm{FVC}=62.7 \pm 16.1 \%$ ) recruited from a pulmonary rehabilitation center. Results: The mean time to complete the Glittre ADL-test was $2.84 \pm 0.45 \mathrm{~min}$. In the stepwise multiple linear regression analysis, age and height were selected as Glittre ADL-test performance predictors, explaining $32.1 \%(p<0.01)$ of the total variance. Equation 1 was as follows: Glittre ADL-test $=3.049+\left(0.015 \times\right.$ age $\left._{\text {years }}\right)+\left(-0.006 \times\right.$ height $\left._{\mathrm{cm}}\right)$. Equation 2 included age and BMI and explained $32.3 \%$ of the variance in the test, the equation being as follows: Glittre $A D L$-test $t_{\text {predicted }}=1.558+(0.018 \times \mathrm{BMI})+\left(0.016 \times\right.$ age $\left._{\text {years }}\right)$. Conclusions: The reference equations for the time to complete the Glittre ADL-test were based on age, BMI, and height as independent variables and can be useful for predicting the performance of adult individuals. The predicted values appear to be reliable when applied to COPD patients.

Keywords: Activities of daily living; Exercise test; Reference values.

. (iD) http://orcid.org/0000-0003-4620-906

d. (iD http://orcid.org/0000-0002-8242-2965

e. (D) http://orcid.org/0000-0002-7813-5592

f. (ID) http://orcid.org/0000-0003-0320-4810

Submitted: 30 April 2017

Accepted: 7 December 2017.

Study carried out at the Núcleo de Assistência, Ensino e Pesquisa em

Reabilitação Pulmonar, Centro de Ciências da Saúde e do Esporte, Universidade do

Estado de Santa Catarina,

Florianópolis (SC) Brasil.

\section{INTRODUCTION}

Reference equations for tests that measure functional capacity are essential for interpreting functional test results, assisting in quantifying the impairment of activities of daily living (ADL) and therapeutic response. Functional status is a multidimensional concept that characterizes the ability that a person has to provide for the necessities of life. ${ }^{(1)}$ Factors such as aging, (2) obesity, ${ }^{(3)}$ and chronic disease, ${ }^{(4)}$ such as COPD, can negatively affect patient functional status. Exercise and ADL limitations are common manifestations in patients with COPD, increasing morbidity and mortality. ${ }^{(5)}$ To evaluate the functional status of COPD patients, Skumlien et al. ${ }^{(6)}$ developed the Glittre ADL-test, which is a standardized set of ADL-like activities known to be difficult for COPD patients. The Glittre ADL-test consists of multiple tasks that require upper and lower limb muscle activity during walking, rising from the seated position, stair climbing/ descending, crouching, kneeling, carrying objects, and lifting objects. ${ }^{(6,7)}$

The Glittre ADL-test is an easily administered, valid, and reliable tool to measure functional status ${ }^{(7)}$ in patients with stable COPD, ${ }^{(6,8,9)}$ exacerbated COPD, ${ }^{(10)}$ heart failure, (11) or community-acquired pneumonia/other respiratory diseases, ${ }^{(10)}$ as well as in obese patients and post-bariatric surgery patients. ${ }^{(12)}$ In addition, the Glittre ADL-test can differentiate between the functional status

Correspondence to:

Anamaria Fleig Mayer. Rua Paschoal Simone, 358, CEP 88080-350, Florianópolis, SC, Brasil.

Tel.: 5548 3664-8608. E-mail: anamaria.mayer@udesc.br

Financial support: None. 
of healthy individuals and that of patients with COPD. ${ }^{8}$ Furthermore, the time to complete the Glittre ADL-test has been shown to correlate with walking and sitting time in COPD patients, as well as with other ADL. ${ }^{(13)}$ Similar physiological responses were found between the Glittre ADL-test and the six-minute walk test (6MWT), oxygen uptake being slightly higher during the Glittre ADL-test. ${ }^{(9)}$

Given that the factors that influence patient performance on the Glittre ADL-test have yet to be determined, ${ }^{(7)}$ there are currently no reference equations to predict patient functional status on the basis of anthropometric and demographic data. Therefore, the objective of the present study was to investigate the influence of the aforementioned variables on patient performance on the Glittre ADL-test in order to generate reference equations for healthy individuals in the 20- to 80 -year age bracket. A secondary objective was to determine the reliability of the equations in a sample of patients with COPD.

\section{METHODS}

\section{Participants}

Apparently healthy individuals were selected from among those living in the city of Florianópolis, Brazil. The inclusion criteria were as follows: being in the 20- to 80-year age bracket and being clinically stable (i.e., having had no severe or unstable disease in the six weeks prior to the study). The exclusion criteria were as follows: post-bronchodilator $\mathrm{FEV}_{1}$ and FVC < $80 \%$ of the predicted value; post-bronchodilator $\mathrm{FEV}_{1} /$ FVC $<0.7$; body mass index $(B M I)<18.5 \mathrm{~kg} / \mathrm{m}^{2}$ or $>40 \mathrm{~kg} / \mathrm{m}^{2}$; active smoking in the six months prior to the study; high physical activity level; and inability to understand or perform any of the tested activities. Of the 223 apparently healthy individuals who were selected to participate, 33 were excluded, 190 having therefore remained in the study.

In order to determine the reliability of the reference equations, 74 COPD patients were selected from among those treated at the Santa Catarina State University Treatment, Education, and Research Center for Pulmonary Rehabilitation, located in the city of Florianópolis, Brazil. Patients $\geq 40$ years of age with Global Initiative for Chronic Obstructive Lung Disease stage II-IV COPD, ${ }^{(5)}$ a smoking history $\geq 20$ packyears, and clinical stability in the four weeks prior to the study were included in the study. The exclusion criteria were as follows: long-term oxygen therapy, current smoking, lung diseases other than COPD, and comorbidities affecting patient ability to perform any of the tested activities.

\section{Study protocol}

Participants were asked questions regarding their medical history, medication use, and smoking history. Patient weight (in $\mathrm{kg}$ ) and height (in $\mathrm{cm}$ ) were measured with a digital scale (Tanita Corporation, Tokyo, Japan) and a portable stadiometer (Sanny; American Medical do Brasil Ltda., São Bernardo do Campo, Brazil), respectively, and the BMI was calculated by the formula weight/height ${ }^{2}\left(\mathrm{~kg} / \mathrm{m}^{2}\right)$. Lung function was assessed with an EasyOne ${ }^{\circledR}$ spirometer (ndd Medical Technologies, Andover, MA, USA), in accordance with the methods and criteria recommended by the American Thoracic Society and the European Respiratory Society, ${ }^{(14)}$ predicted values being calculated. ${ }^{(15)}$

Participants performed the Glittre ADL-test twice, with a 30-min interval between tests. The shorter of the two tests was selected for data analysis. In individuals in the 20- to 59-year age bracket and in those in the 60- to 80-year age bracket the level of physical activity was measured by the short form of the International Physical Activity Questionnaire ${ }^{(16)}$ and the version that has been adapted for use in Brazilian elderly individuals, ${ }^{(17)}$ respectively.

The group of COPD patients underwent anthropometric measurements, pulmonary function testing, the Glittre ADL-test, and the 6MWT. The 6MWT was performed indoors along a flat, straight, 20-m corridor, in accordance with the American Thoracic Society guidelines. ${ }^{(18,19)}$ The percent predicted six-minute walk distance (6MWD) was calculated on the basis of an equation developed by Britto et al. ${ }^{(20)}$

All participants gave written informed consent. The study was approved by the Research Ethics Committee of the Santa Catarina State University (Protocol no. 225/2011).

\section{Glittre ADL-test}

The Glittre ADL-test was performed as described by Skumlien et al. ${ }^{(6)}$ and comprises the following tasks: walking along a flat surface; stair climbing and descending; moving objects from one shelf to another (as well as putting them on the floor and back on the shelves); and rising from and sitting in a chair. Female participants carried a backpack weighing $2.5 \mathrm{~kg}$, whereas male participants carried a backpack weighing 5.0 kg. ${ }^{(6)}$ Heart rate, pulse oximetry, dyspnea (modified Borg scale), (21) and blood pressure were measured.

\section{Statistical analysis}

Statistical analysis was performed with the IBM SPSS Statistics software package, version 20.0 (IBM Corporation, Armonk, NY, USA) and the GraphPad Prism software, version 5.0 (GraphPad Inc., San Diego, CA, USA). The sample size required to generate a reference equation for healthy individuals in the 20- to 80-year age bracket was calculated by the following formula:

$\mathrm{N}>50+8 m$

where $\mathrm{m}$ is the number of independent variables. ${ }^{(22)}$

For five independent variables based on the theoretical assumptions (gender, age, height, weight, and $\mathrm{BMI}){ }^{(20,23-28)}$ the minimum sample size was calculated to be 90 . Given that the study sample comprised individuals in the 20- to 80-year age bracket, it was divided into six age groups (20-29 years; 30-39 years; 40-49 years; $50-59$ years; $60-69$ years; and $70-80$ years), 
each of which comprised at least 14 individuals. The sample size required to maintain a balance between the genders was calculated to be 190 .

Data were expressed as mean \pm standard deviation or median $(95 \% \mathrm{CI})$. The normality of the data was verified with the Kolmogorov-Smirnov test. Comparisons were performed with the Wilcoxon test, the Mann-Whitney test, or the independent sample t-test.

The association between the time to complete the Glittre ADL-test and the independent variables was tested by simple linear regression analysis. Stepwise multiple linear regression analysis was used in order to evaluate independent variables explaining the variance in the Glittre ADL-test. The normality of the residuals was verified graphically (histogram and Q-Q plot), and multicollinearity was assessed by examining tolerance $\left(1-r^{2}\right)$ and variance inflation factor $\left(1 / 1-r^{2}\right) .^{(29)}$ Reliability was assessed by Spearman's correlation coefficient, linear regression analysis, and the intraclass correlation coefficient (ICC). In addition, a paired-sample t-test or the Wilcoxon test was used in order to compare the actual time to complete the Glittre ADL-test with the predicted value. $(20,30)$ The age-predicted maximal heart rate was calculated by the following formula: $208-0.7^{*}$ age $_{\text {years }}{ }^{(31)}$ Bland-Altman plots ${ }^{(29,31)}$ were used in order to evaluate the agreement between the actual time to complete the Glittre ADL-test and the predicted value. ${ }^{(30,32)}$ The significance level was set at $p=0.05$ for all analyses.

\section{RESULTS}

Of the 223 apparently healthy individuals who were selected to participate, 190 had normal lung function and completed the study (Table 1). Of those, 95 were male. A total of 33 individuals were excluded, for the following reasons: restrictive or obstructive lung disease, in 17; inability to understand or perform any of the tested activities, in 14; active smoking in the six months prior to the study, in 1; and high self-reported physical activity, in 1 . Of the 190 apparently healthy participants, 152 (80\%) were classified as physically active. In addition, $51.5 \%$ were nonsmokers and $30.5 \%$ were former smokers. Self-reported comorbidities included systemic hypertension (in 25\%), metabolic disorders (in 14.9\%), thyroid disorders (in 8.2\%), stable cardiac disease (in 2.6\%), and osteoporosis (in $1.3 \%$ ).

A total of 151 participants (79.5\%) performed better on the second Glittre ADL-test than on the first. There was a 0.16 reduction in the mean time to complete the second test in comparison with the first $(0.21 \mathrm{~min}$; $p<0.01$ ), with a $5.3 \%$ learning effect. The best test was completed in $2.84 \pm 0.45 \mathrm{~min}$ ( $2 \mathrm{~min}$ and $50 \mathrm{~s}$ ). The shortest and longest tests were $1.92 \mathrm{~min}$ (1 $\mathrm{min}$ and $55 \mathrm{~s}$ ) and $4.17 \mathrm{~min}$ (4 min and $10 \mathrm{~s}$ ) in duration, respectively. The median time to complete the first test was 2.95 min (range, 2.95-3.09), i.e., 2 min and $57 \mathrm{~s}$, and the median time to complete the second test was 2.82 min (range, 2.80-2.92), i.e., 2 min and
$49 \mathrm{~s}(\mathrm{p}<0.01)$. With the exception of systolic blood pressure, there were no differences in physiological variables between the first and second tests (Table 2). An ICC of 0.95 (95\% CI: 0.93-0.96; p < 0.01) was found between the time to complete the first test and the time to complete the second test. There was no significant difference between males and females regarding their performance on the Glittre ADL-test $(p=0.35)$.

The simple linear regression analysis showed that the performance on the Glittre ADL-test was significantly associated with age $\left(R^{2}=0.30 ; p<0.01\right)$, height $\left(R^{2}\right.$ $=0.09 ; p<0.01)$, and BMI $\left(R^{2}=0.05 ; p=0.01\right)$ but not with weight or gender. In the stepwise multiple linear regression analysis, age and height were selected as Glittre ADL-test performance predictors, explaining $32.1 \%(p<0.01)$ of the total variance. In addition, BMI and age explained $32.3 \%(p<0.01)$ of the total variance when only participants with a BMI of $<35$ $\mathrm{kg} / \mathrm{m}^{2}$ were taken into account.

The reference equation for the Glittre ADL-test was as follows $\left(R^{2}=0.321\right)$ :

Glittre ADL-test predicted $=3.049+\left(0.015 \times\right.$ age $\left._{\text {years }}\right)+$ $\left(-0.006 \times\right.$ height $\left._{\mathrm{cm}}\right)$

A second equation was generated by excluding the participants with a BMI $\geq 35 \mathrm{~kg} / \mathrm{m}^{2}\left(\mathrm{R}^{2}=0.323\right)$ :

Glittre ADL-test
$\left(0.016 \times\right.$ age $\left._{\text {pears }}\right)$

No multicollinearity was present (Table 3 ). The Bland-Altman plots showed good agreement between the actual time to complete the Glittre ADL-test and the predicted values in the group of healthy individuals (Figures $1 \mathrm{~A}$ and $\mathrm{C}$ ) but not in the group of patients with COPD (Figures $1 B$ and D).

The reliability of the reference equations for the Glittre ADL-test was tested in 74 COPD patients (Table 1 ). An ICC of 0.97 ( $95 \%$ CI: 0.95-0.98; p < 0.01) was found between the time to complete the first test and the time to complete the second test. A strong correlation was found between the mean time to complete the Glittre ADL-test $(4.70 \pm 1.9 \mathrm{~min} ; 147.4 \pm 57.6 \%$ of the predicted value) and the mean 6MWD (435.1 \pm $101.1 \mathrm{~m} ; 78.4 \pm 17.4 \%$ of the predicted value; $r=$ $-0.81 ; p<0.01)$. In addition, a strong correlation was found between percent predicted values for equation 1 $(r=-0.74 ; p<0.01)$ and equation $2(r=-0.86 ; p<$ 0.01 ; Figure 2$)$, with a significant association between the two (equation $1: \mathrm{R}^{2}=0.51$; equation $2: \mathrm{R}^{2}=0.65$; $p<0.01)$. Significant differences were found between the actual performance on the Glittre ADL-test and the predicted values for the two equations $(p<0.05)$.

\section{DISCUSSION}

To our knowledge, this is the first study to establish reference equations for the Glittre ADL-test on the basis of how healthy individuals perform on the test. The mean time to complete the Glittre ADL-test was $2.84 \mathrm{~min}$ ( $2 \mathrm{~min}$ and $50 \mathrm{~s}$ ). Among the independent 
Table 1. Characteristics of the study sample. ${ }^{a}$

\begin{tabular}{|c|c|c|c|c|}
\hline Variable & $\begin{array}{l}\text { Healthy individuals } \\
\qquad(n=190)\end{array}$ & $\begin{array}{l}\text { Healthy males } \\
(n=95)\end{array}$ & $\begin{array}{l}\text { Healthy females } \\
\qquad(\mathrm{n}=95)\end{array}$ & $\begin{array}{l}\text { COPD patients } \\
(n=74)\end{array}$ \\
\hline Age, years ${ }^{b}$ & $54.5(42-65)$ & $54(43-64)$ & $56(41-65)$ & $66(59-73)$ \\
\hline \multicolumn{5}{|l|}{ Age groups ${ }^{c}$} \\
\hline $20-29$ & $16(8.4)$ & $7(7.4)$ & $9(9.5)$ & - \\
\hline $30-39$ & $18(9.5)$ & $8(8.4)$ & $10(10.5)$ & - \\
\hline $40-49$ & $42(22.1)$ & $25(26.3)$ & $17(17.9)$ & $4(5.4)$ \\
\hline $50-59$ & $45(23.7)$ & $24(25.3)$ & $21(22.1)$ & $15(20.3)$ \\
\hline $60-69$ & $38(20)$ & $17(17.9)$ & $21(22.1)$ & $33(44.6)$ \\
\hline $70-80$ & $31(16.3)$ & $14(14.7)$ & 17 (17.9) & $22(29.7)$ \\
\hline Weight, kg & $72.8(12.8)$ & $78.6(12.0)$ & $67.1(10.9)^{*}$ & $72.3(15.1)$ \\
\hline Height, $\mathrm{cm}^{\mathrm{b}}$ & $166(159-174)$ & $174(169-178)$ & $159(154-163)^{*}$ & 167 (159-173) \\
\hline $\mathrm{BMI}, \mathrm{kg} / \mathrm{m}^{2 \mathrm{~b}}$ & $25.6(23.4-28.9)$ & 25.4 (24-27.9) & $26.0(22.7-29.9)$ & $25.3(22.1-29.6)$ \\
\hline \multicolumn{5}{|l|}{ BMI categories ${ }^{c}$} \\
\hline Normal weight & $85(44.7)$ & $44(46.3)$ & $41(43.2)$ & $35(47.3)$ \\
\hline Overweight & 72 (37.9) & $40(42.1)$ & $32(33.7)$ & $23(31.1)$ \\
\hline Obesity & $33(17.4)$ & $11(11.6)$ & $22(23.2)$ & $16(21.6)$ \\
\hline $\mathrm{FEV}_{1} / \mathrm{FVC}^{\mathrm{b}}$ & $0.83(0.79-0.87)$ & $0.85(0.79-0.87)$ & $0.82(0.79-0.87)$ & $0.43(0.38-0.52)$ \\
\hline $\mathrm{FEV}_{1}, \%$ predicted $^{\mathrm{b}}$ & $97(91-105.2)$ & $97(91-106)$ & $97(90-105.2)$ & $35.5(24.7-45.0)$ \\
\hline FVC, \% predicted ${ }^{b}$ & $96(88.5-102)$ & $94(86-101)$ & $96(90-102.5)$ & $61(51-73.2)$ \\
\hline Glittre ADL-test, $\min ^{\mathrm{b}}$ & $2.80(2.52-3.10)$ & $2.75(2.43-3.13)$ & $2.85(2.60-3.08)$ & $4.11(3.46-5.24)$ \\
\hline
\end{tabular}

BMI: body mass index; and ADL: activities of daily living. aData expressed as mean \pm SD, except where otherwise indicated. 'Data expressed as median (interquartile range). 'Data expressed as frequency (relative frequency). ${ }^{*} \mathrm{p}$ $<0.05$ vs. males.

Table 2. Differences in physiological parameters between the two Glittre ADL-tests performed by healthy individuals. ${ }^{\mathrm{a}}$

\begin{tabular}{|c|c|c|c|}
\hline Variable & Glittre ADL-test 1 & Glittre ADL-test 2 & p \\
\hline Glittre ADL-test, min & $2.95(2.66-3.33)$ & $2.82(2.52-3.12)$ & $<0.01$ \\
\hline Baseline HR, bpm & $77.0(70.0-86.0)$ & $77.0(71.0-86.0)$ & 0.91 \\
\hline$\Delta \mathrm{HR}, \mathrm{bpm}$ & $39.0(30.0-46.0)$ & $38.5(29.0-50.0)$ & 0.64 \\
\hline Age-predicted $\mathrm{HR}_{\max }$ & $69.7(61.8-78.3)$ & $68.9(62.2-79.2)$ & 0.99 \\
\hline Initial SBP, mmHg & $120.0(110.0-130.0)$ & $120.0(110.0-130.0)$ & 0.02 \\
\hline Final SBP, mmHg & $140.0(130.0-160.0)$ & $140.0(130.0-152.5)$ & 0.13 \\
\hline$\triangle \mathrm{SBP}, \mathrm{mmHg}$ & $20.0(10.0-30.0)$ & $20.0(20.0-30.0)$ & 0.55 \\
\hline Initial DBP, mmHg & $80.0(70.0-80.0)$ & $80.0(70.0-80.0)$ & 0.45 \\
\hline Final DBP, mmHg & $80.0(70.0-90.0)$ & $80.0(70.0-90.0)$ & 0.55 \\
\hline$\triangle \mathrm{DBP}, \mathrm{mmHg}$ & $0(0-10.0)$ & $0(0-10.0)$ & 0.84 \\
\hline Initial Borg score & $0(0-0)$ & $0(0-0)$ & 0.55 \\
\hline Final Borg score & $0.5(0-1.0)$ & $0.0(0-1.0)$ & 0.81 \\
\hline$\Delta$ Borg score & $0.5(0.0-1.0)$ & $0.0(0-1.0)$ & 0.88 \\
\hline
\end{tabular}

ADL: activities of daily living; $\Delta$ : variation (final value - baseline value); SBP: systolic blood pressure; DBP: diastolic blood pressure; and Borg: Borg dyspnea scale. aData expressed as median (interquartile range).

variables, age and height were found to be significant independent predictors, explaining $32.1 \%$ of the variance in the Glittre ADL-test when individuals with a BMI of $18.5-40 \mathrm{~kg} / \mathrm{m}^{2}$ were taken into account (equation 1 ). However, when individuals with a BMI $\geq 35 \mathrm{~kg} / \mathrm{m}^{2}$ were excluded (equation 2), age and BMI accounted for $32.3 \%$ of the variance in the test.

Of the 190 healthy participants, 79.5\% performed better on the second Glittre ADL-test. The learning effect was $5.3 \%$, and the shortest test was $1.92 \mathrm{~min}$ (1 min and $55 \mathrm{~s}$ ) in duration. Skumlien et al. ${ }^{(6)}$ found that the shortest test among healthy individuals was 2 min in duration. However, the demographic and anthropometric characteristics of those individuals were not mentioned. In a previous study, our research group showed that healthy individuals in the 20- to 39-year age bracket completed the Glittre ADL-test in $2.62 \pm 0.34 \mathrm{~min}(2 \mathrm{~min}$ and $37 \mathrm{~s})$, the shortest test having lasted $2.03 \mathrm{~min}$ ( $2 \mathrm{~min}$ and $2 \mathrm{~s}$ ), with a $6.3 \%$ learning effect. ${ }^{(33)}$ Therefore, it is possible that individuals who complete the test in approximately 2 min have preserved functional capacity.

Anthropometric and demographic variables are usually helpful to determine individual performance on functional tests. ${ }^{(20,23-25)}$ Therefore, we hypothesized that variables such as age, height, BMI, weight, and gender would be predictors of the time to complete the Glittre ADL-test. 
Table 3. Model for predicting the time to complete the Glittre ADL-test.

\begin{tabular}{|c|c|c|c|c|c|c|}
\hline Variable & $\begin{array}{l}\text { Unstandardized } \\
\text { coefficient (B) }\end{array}$ & $95 \% \mathrm{Cl}$ for $\mathrm{B}$ & $\mathbf{p}$ & $\begin{array}{c}\text { Part } \\
\text { correlation }\end{array}$ & Tolerance & $\begin{array}{c}\text { Variance } \\
\text { inflation factor }\end{array}$ \\
\hline \multicolumn{7}{|l|}{ Equation 1} \\
\hline Constant & 3.049 & $2.095-4.004$ & $<0.01$ & & & \\
\hline Age, years & 0.015 & $0.011-0.019$ & $<0.01$ & 0.503 & 0.902 & 1.109 \\
\hline Height, $\mathrm{cm}$ & -0.006 & -0.011 to -0.001 & 0.02 & -0.163 & 0.902 & 1.109 \\
\hline \multicolumn{7}{|l|}{ Equation 2} \\
\hline Constant & 1.558 & $1.142-1.974$ & $<0.01$ & & & \\
\hline BMI & 0.018 & $0.002-0.033$ & $<0.01$ & 0.165 & 0.963 & 1.038 \\
\hline Age, years & 0.016 & $0.012-0.019$ & $<0.01$ & 0.530 & 0.963 & 1.038 \\
\hline
\end{tabular}

ADL: activities of daily living; and BMI: body mass index. Equation 1: Glittre ADL-test predicted $_{1}=3.049+(0.015 \times$ age $\left._{\text {years }}\right)+\left(-0.006 \times\right.$ height $\left._{\mathrm{cm}}\right)$; standard error of the estimate $=0.371$. Equation 2: Glittre ADL-test predicted $=1.558$ $+(0.018 \times \mathrm{BMI})+\left(0.016 \times\right.$ age $\left._{\text {years }}\right) ;$ standard error of the estimate $=0.373$.

(A)

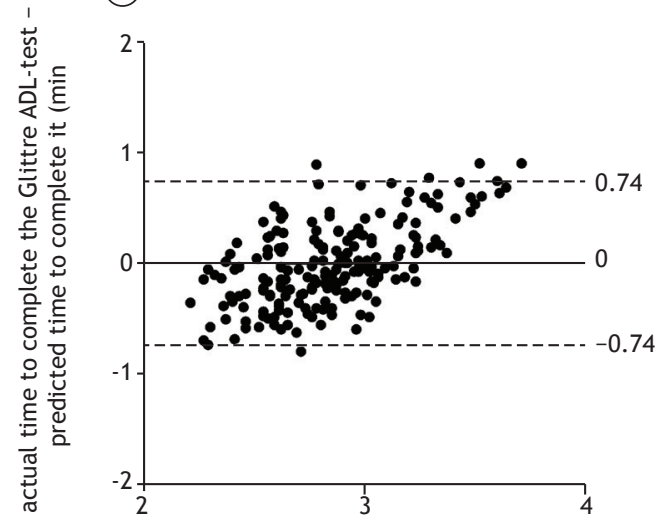

(actual value + predicted value) $\div 2$

(C)

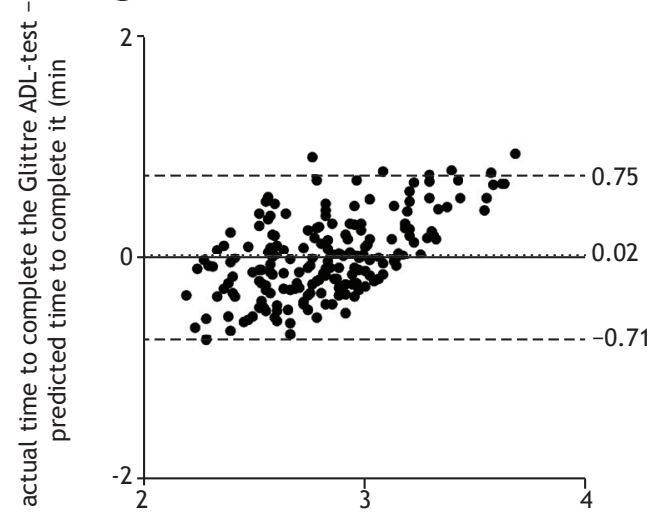

(actual value + predicted value $) \div 2$
(B)

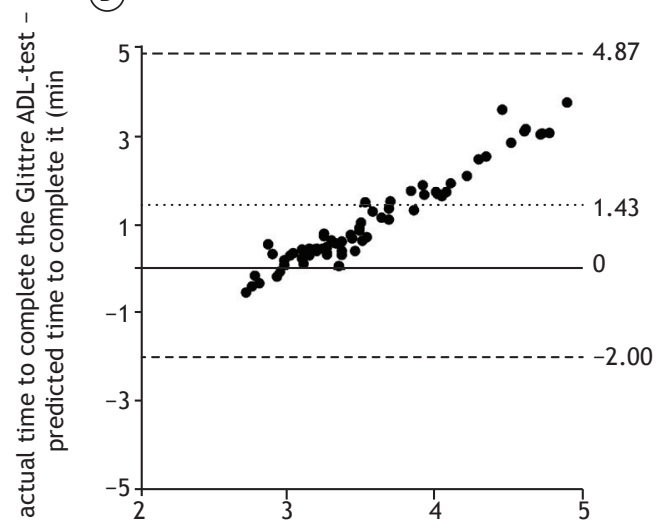

(actual value + predicted value) $\div 2$

(D)

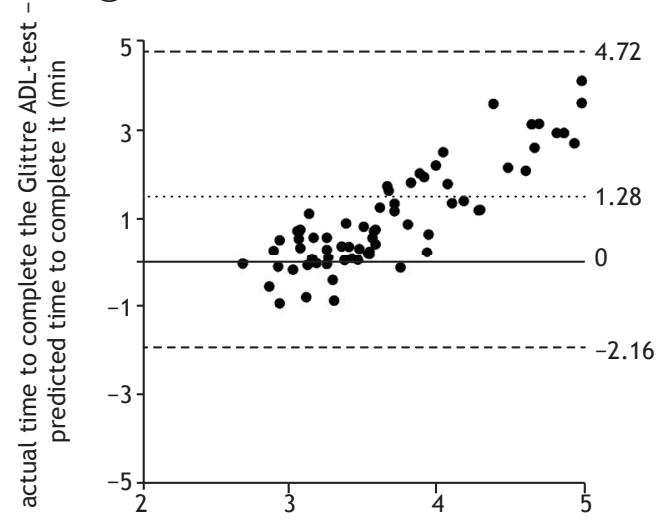

(actual value + predicted value) $\div 2$

Figure 1. Bland-Altman plots of the difference between the actual time to complete the Glittre ADL-test and the predicted time to complete it (in $\mathrm{min}$ ), and the mean of the actual and predicted values for healthy individuals $(A$ and $C)$ and COPD patients ( $B$ and $D$ ). The central dotted line represents the mean difference between the actual and predicted values, whereas the upper and lower dashed lines represent the upper and lower limits of agreement, respectively. ADL: activities of daily living. Equation 1: Glittre ADL-test ${ }_{\text {predicted }}=3.049+\left(0.015 \times\right.$ age $\left._{\text {years }}\right)+\left(-0.006 \times\right.$ height $\left._{c m}\right)$. Equation 2: Glittre ADL-test ${ }_{\text {predicted }}=1.558+(0.018 \times \mathrm{BMI})+\left(0.016 \times\right.$ age $\left._{\text {years }}\right)$. Panels A and B refer to equation 1 , whereas panels $C$ and $D$ refer to equation 2.

Age was the only independent variable that remained in the two equations. Aging affects muscle mass, strength, resistance, balance, and coordination-all of which are components of functional capacity-leading to a progressive physical decline even in healthy physically active individuals. ${ }^{(34)}$ In the present study, age was related to a longer time to complete the Glittre ADL-test. This might be due to tasks such as 
(A)

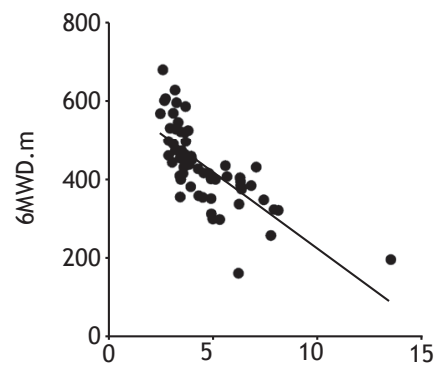

Glittre ADL-test, min
(B)

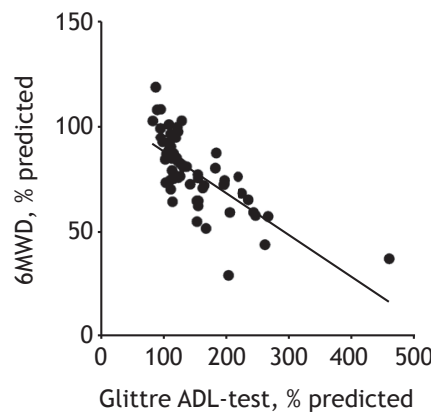

(C)

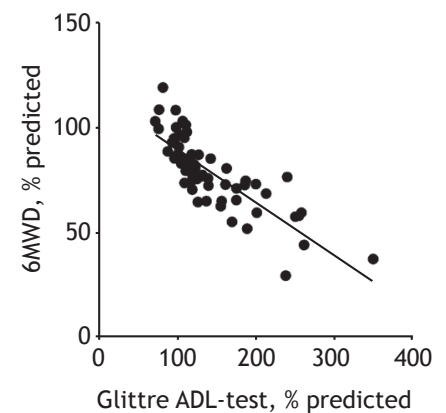

Figure 2. In $A$, correlation between the time to complete the Glittre ADL-test, in min, and the six-minute walk distance (6MWD), in $\mathrm{m}(\mathrm{r}=-0.81 ; \mathrm{p}<0.01)$. In $\mathrm{B}$, correlation between the percent predicted Glittre ADL-test value (as predicted by equation 1) and the percent predicted $6 \mathrm{MWD}^{(20)}(r=-0.74 ; p<0.01)$. In $\mathrm{C}$, correlation between the percent predicted Glittre ADL-test value (as predicted by equation 2 ) and the percent predicted $6 M W D(20)(r=-0.86$; $p<0.01)$. ADL: activities of daily living. Equation 1: Glittre $A D L$-test predicted $=3.049+\left(0.015 \times\right.$ age $\left._{\text {years }}\right)+\left(-0.006 \times\right.$ height $\left._{\mathrm{cm}}\right)$. Equation 2: Glittre ADL-test predicted $=1.558+(0.018 \times \mathrm{BMI})+\left(0.016 \times\right.$ age $\left._{\text {years }}\right)$.

sitting in and rising from a chair, walking, crouching/ kneeling, and stair climbing/descending. The ability to rise from a chair deteriorates with age; aging is a major source of disability and impaired autonomy, being highly associated with loss of quadriceps strength. (35) Age is also an important predictor of walking speed, being included as a variable in equations for several functional status tests, such as the 6MWT and the incremental shuttle walk test. $(23,26,27,36,37)$ In addition to walking, individuals performing the Glittre ADL-test are required to crouch and kneel, which are activities that a quarter of older adults have difficulty in performing or are unable to perform; this is probably due to ankle plantar flexor and knee weakness, as well as to balance impairment. ${ }^{(38)}$ Stair climbing and descending are also compromised in elderly individuals, because of reduced muscle strength, reduced balance, pain, fear of falling, and impaired sensation. (38)

In the second of the two equations generated in the present study, the BMI was the predictor with the highest coefficient. Previous studies have shown the influence of the BMI on patient performance on functional tests such as the $6 \mathrm{MWT}^{(20,27)}$ and the incremental shuttle walk test. ${ }^{(23)}$ In the present study, a higher BMI translated to a worse performance on the Glittre ADL-test. Obesity increases the workload for a given activity, ${ }^{(25)}$ and body composition is significantly associated with walking speed and endurance, ${ }^{(39)}$ as well as with walking performance and the ability to perform the sit-to-stand test without assistance. ${ }^{(35)}$

Although it could be argued that the inclusion of patients with a BMI $\geq 35 \mathrm{~kg} / \mathrm{m}^{2}$ introduced a bias in the present study because reference values should be derived from normal individuals, a decision was made to include such patients in the model for equation 1 but exclude them from the model for equation 2 . In a real-life scenario, health professionals habitually encounter chronic respiratory disease patients with class II or III obesity and should be able to calculate the predicted values for functional capacity tests in such patients. There is controversy in the literature regarding this issue, such patients having been excluded from some studies ${ }^{(24,25,40)}$ but not from others. ${ }^{(20,23,26-28)}$ Given that the two equations were found to have similar coefficients of determination and similar statistical properties, the choice between the two should be made on the basis of the BMI.

We had hypothesized that weight and height were predictors of a longer time to complete the Glittre ADL-test and a shorter time to complete the test, respectively. Overweight influences gait and increases the workload on horizontal and vertical displacements, which occur during the Glittre ADL-test tasks of walking, sitting/standing, stair climbing/descending, and crouching/kneeling. ${ }^{(41)}$ However, weight was not retained in either equation.

Despite its low coefficient, height was considered to be an independent predictor of performance on the Glittre ADL-test, although only for equation 1 . This might be due to the fact that the taller the person, the longer his or her legs and, consequently, the longer his or her stride, their walking therefore being more efficient ${ }^{(25)}$ and contributing to a shorter time to complete the Glittre ADL-test.

Gender was found to have no influence on the time to complete the Glittre ADL-test, a finding that is consistent with those of other studies examining patient functional status. $(23,24,27,28,33)$ The lack of association between gender and the time to complete the Glittre ADL-test might be partly explained by the lack of statistical difference between males and females regarding their performance on the test. In addition, it is possible that the heavier backpack carried by males influenced their performance and compensated for potential fitness differences between the genders. Although Skumlien et al. (6) had females carrying a backpack weighing 2.5 $\mathrm{kg}$ and males carrying a backpack weighing $5.0 \mathrm{~kg}$, the impact of this additional weight on male performance on the Glittre ADL-test remains unclear. 
Although the reliability of a reference equation is usually confirmed in healthy individuals, our equations were tested in COPD patients because the Glittre ADL-test was validated for use in and is primarily administered to such patients. In addition, the significance of the time to complete the Glittre ADL-test has yet to be established. Therefore, the 6MWD and its predicted value were selected to test the reliability of the derived equations, because the 6MWT and the Glittre ADL-test were designed to assess functional capacity and because the latter has been found to correlate strongly with the former in COPD patients. ${ }^{(6,9)}$ In the present study, the predicted Glittre ADL-test value was strongly correlated with the percent predicted 6MWD, which was calculated on the basis of an equation developed by Britto et al. ${ }^{(20)}$ The reference equations for the Glittre ADL-test were found to be reliable because they evidenced the impaired functional status of the patients with COPD, for whom the mean time to complete the test was approximately $45.2 \%$ longer than the expected maximum time to complete it. It could be argued that there is poor agreement between actual and predicted values for patients with COPD, especially those with worse functional impairment. However, the proposed equations are expected to underestimate the predicted values because it takes patients with COPD longer to complete the Glittre ADL-test than it does healthy individuals, ${ }^{(6,8,33)}$ COPD patients therefore showing values $>100 \%$ of the predicted value. Therefore, the worse the functional impairment, the more the actual performance on the Glittre ADL-test will differ from the predicted value derived from apparently healthy individuals. This reinforces the fact that the Glittre ADL-test is better at differentiating between patients with severe functional limitations ${ }^{(6)}$ and those with preserved functional capacity, given that it takes the latter group of patients almost the same time to complete the test as it does healthy individuals (i.e., approximately $3 \mathrm{~min}$ ). As expected, poor agreement, moderate correlations, and significant differences were found between the actual performance on the Glittre ADL-test and the predicted value in the group of COPD patients investigated in the present study.

The present study has some limitations that should be noted. Although we calculated the required sample size for the study and attempted to maintain a balance between the genders and the numbers of individuals in each age group, ours was a convenience sample. Given that only approximately $32 \%$ of the variance in the time to complete the Glittre ADL-test was explained by the derived equations, it remains to be determined whether other factors, such as balance, peripheral muscle strength, behavior, cognition, and physiological factors, have any influence on the time to complete the test. However, it should be noted that studies aimed at generating reference equations for the 6MWT have shown a variance similar to that observed in the present study, having included independent variables similar to those included in the present study. $(24,25,28,40)$ In order to prioritize clinical practice, we investigated the reliability of our reference equations in a group of COPD patients, in whom impaired functional capacity was evidenced by establishing a relationship between their performance on the Glittre ADL-test and their performance on the 6MWT and by comparing their performance on the Glittre ADL-test with that of healthy individuals. Therefore, future studies should investigate the reliability of the equations in healthy individuals.

In summary, the two equations generated in the present study can explain approximately $32 \%$ of the variance in the time to complete the Glittre ADL-test. The choice of equation for use depends on the BMI. The predicted values appear to be reliable when applied to patients with COPD.

\section{REFERENCES}

1. Leidy N. Functional status and the forward progress of merrygo-rounds: toward a coherent analytical framework. Nurs Res 1994;43(4):196-202. https://doi.org/10.1097/00006199-19940700000002

2. World Health Organization. World report on disability: Geneva: World Health Organization; 2011.

3. Jensen $G L$, Hsiao PY. Obesity in older adults: relationship to functional limitation. Curr Opin Clin Nutr Metab Care. 2010;13(1):46 51. https://doi.org/10.1097/MC0.0b013e32833309cf

4. Fiedler MM, Peres KG. Functional status and associated factors among the elderly in a southern Brazilian city: a population-based study [Article in Portuguese]. Cad Saude Publica. 2008;24(2):409-15. https://doi.org/10.1590/S0102-311X2008000200020

5. Global Initiative for Chronic Obstructive Lung Disease (GOLD) [homepage on the Internet]. Bethesda: GOLD; [cited 2017 Jan 20] Global Strategy for the Diagnosis, Management and Prevention of COPD 2016. Available from: http://www.goldcopd.org/

6. Skumlien S, Hagelund T, Bjørtuft O, Ryg MS. A field test of functional status as performance of activities of daily living in COPD patients. Respir Med. 2006;100(2):316-23. https://doi.org/10.1016/j. rmed.2005.04.022

7. Bui KL, Nyberg A, Maltais F, Saey D. Functional Tests in Chronic Obstructive Pulmonary Disease, Part 2: Measurement Properties. Ann Am Thorac Soc. 2017;14(5):785-794. https://doi.org/10.1513/

AnnalsATS.201609-734AS

8. Corrêa KS, Karloh M, Martins LQ, Santos Kd, Mayer AF. Can the Glittre ADL test differentiate the functional capacity of COPD patients from that of healthy subjects? Rev Bras Fisioter. 2011;15(6):467-73. https://doi.org/10.1590/S1413-35552011005000034

9. Karloh M, Karsten M, Pissaia FV, de Araujo CL, Mayer AF. Physiologica responses to the Glittre-ADL test in patients with chronic obstructive pulmonary disease. J Rehabil Med. 2014;46(1):88-94. https://doi. org/10.2340/16501977-1217

10. José A, Dal Corso S. Reproducibility of the six-minute walk test and Glittre ADL-test in patients hospitalized for acute and exacerbated chronic lung disease. Braz J Phys Ther. 2015;19(3):235-42. https:// doi.org/10.1590/bjpt-rbf.2014.0092

11. Valadares YD, Corrêa KS, Silva BO, Araujo CL, Karloh M, Mayer AF. Applicability of activities of daily living tests in individuals with heart failure. Rev Bras Med Esporte. 2011;17(5):310-4. https://doi org/10.1590/S1517-86922011000500003

12. Monteiro F, Ponce DA, Silva H, Carrilho AF, Pitta F. Validity and Reproducibility of the Glittre ADL-Test in Obese and Post-Bariatric Surgery Patients. Obes Surg. 2017;27(1):110-114. https://doi. org/10.1007/s11695-016-2244-7

13. Karloh M, Araujo CL, Gulart AA, Reis CM, Steidle LJ, Mayer AF The Glittre-ADL test reflects functional performance measured by physical activities of daily living in patients with chronic obstructive 
pulmonary disease. Braz J Phys Ther. 2016;20(3):223-30. https://doi. org/10.1590/bjpt-rbf.2014.0155

14. Miller MR, Hankinson J, Brusasco V, Burgos F, Casaburi R, Coates A, et al. Standardisation of spirometry. Eur Respir J. 2005;26(2):319-38. https://doi.org/10.1183/09031936.05.00034805

15. Pereira CA, Sato T, Rodrigues SC. New reference values for forced spirometry in white adults in Brazil. J Bras Pneumol. 2007;33(4):397406. https://doi.org/10.1590/S1806-37132007000400008

16. Matsudo S, Araújo T, Marsudo V, Andrade D, Andrade E, Braggion G. Questinário internacional de atividade física (IPAQ): estudo de validade e reprodutibilidade no Brasil. Rev Bras Ativ Fis Saude. 2001;6(2):5-18.

17. Mazo GZ, Benedetti TR. Adaptação do questionário internacional de atividade física para idosos. Rev Bras Cineantropom Desemp Hum. 2010;12(6):480-4. https://doi.org/10.5007/19800037.2010v12n6p480

18. ATS Committee on Proficiency Standards for Clinical Pulmonary Function Laboratories. ATS statement: guidelines for the six-minute walk test. Am J Respir Crit Care Med. 2002;166(1):111-7. https://doi. org/10.1164/ajrccm.166.1.at1102

19. Holland AE, Spruit MA, Troosters T, Puhan MA, Pepin V, Saey $D$, et al. An official European Respiratory Society/American Thoracic Society technical standard: field walking tests in chronic respiratory disease. Eur Respir J. 2014;44(6):1428-46. https://doi. org/10.1183/09031936.00150314

20. Britto RR, Probst VS, de Andrade AF, Samora GA, Hernandes NA, Marinho PE, et al. Reference equations for the six-minute walk distance based on a Brazilian multicenter study. Braz J Phys Ther. 2013;17(6):556-63. https://doi.org/10.1590/S141335552012005000122

21. Borg GA. Psychophysical bases of perceived exertion. Med Sc Sports Exerc. 1982;14(5):377-81. https://doi.org/10.1249/00005768198205000-00012

22. Tabachnick BG, Fidell LS. Multiple Regression. Using Multivariate Statistics. 5th ed. Boston: Pearson Education Inc; 2007.

23. Probst VS, Hernandes NA, Teixeira DC, Felcar JM, Mesquita RB, Goncalves CG, et al. Reference values for the incremental shuttle walking test. Respir Med. 2012;106(2):243-8. https://doi. org/10.1016/j.rmed.2011.07.023

24. Troosters T, Gosselink R, Decramer M. Six minute walking distance in healthy elderly subjects. Eur Respir J. 1999;14(2):270-4. https:// doi.org/10.1034/j.1399-3003.1999.14b06.x

25. Enright PL, Sherrill DL. Reference equations for the six-minute walk in healthy adults. Am J Respir Crit Care Med. 1998;158(5 Pt 1):13847. https://doi.org/10.1164/ajrccm.158.5.9710086

26. Iwama AM, Andrade GN, Shima P, Tanni SE, Godoy I, Dourado VZ. The six-minute walk test and body weight-walk distance product in healthy Brazilian subjects. Braz J Med Biol Res. 2009;42(11):1080-5. https://doi.org/10.1590/S0100-879X2009005000032
27. Soares MR, Pereira CA. Six-minute walk test: reference values fo healthy adults in Brazil. J Bras Pneumol. 2011;37(5):576-83. https:// doi.org/10.1590/S1806-37132011000500003

28. Camarri B, Eastwood PR, Cecins NM, Thompson PJ, Jenkins S. Six minute walk distance in healthy subjects aged 55-75 years. Respir Med. 2006;100(4):658-65. https://doi.org/10.1016/j. rmed.2005.08.003

29. Field A. Discovering Statistics. Using IBM SPSS Statistics. Thousand Oaks (CA): SAGE Publications; 2013.

30. Bruton A, Conway JH, Holgate ST. Reliability: what is it, and how is it measured? Physiotherapy. 2000;86(2):94-9. https://doi.org/10.1016/ S0031-9406(05)61211-4

31. Tanaka H, Monahan KD, Seals DR. Age-predicted maximal heart rate revisited. J Am Coll Cardiol. 2001;37(1):153-6. https://doi. org/10.1016/S0735-1097(00)01054-8

32. Bland JM, Altman DG. Measuring agreement in method comparison studies. Stat Methods Med Res. 1999;8(2):135-60. https://doi. org/10.1177/096228029900800204

33. Reis $C M$, Silva $T C$, Karloh $M$, Araujo $C L$, Gulart $A A$, Mayer $A F$. Performance of healthy adult subjects in Glittre ADL-test. Fisioter Pesqui. 2015;22(1):41-7.

34. Hughes PD, Polkey MI, Harrus ML, Coats AJ, Moxham J, Green M. Diaphragm strength in chronic heart failure. Am J Respir Crit Care Med. 1999;160(2):529-34. https://doi.org/10.1164/ ajrccm.160.2.9810081

35. Bohannon RW. Body mass index and mobility of older home care patients. Physiother Theory Pract. 2011;27(6):460-2. https://doi.org/1 0.3109/09593985.2010.523058

36. Pearce ME, Cunningham DA Donner AP, Rechnitzer PA, Fullerton $\mathrm{GM}$, Howard JH. Energy cost of treadmill and floor walking at selfselected paces. Eur J Appl Physiol Occup Physiol. 1983;52(1):115-9. https://doi.org/10.1007/BF00429037

37. Hernandez ME, Goldberg A, Alexander NB. Decreased muscle strength relates to self-reported stooping, crouching, or kneeling difficulty in older adults. Phys Ther. 2010;90(1):67-74. https://doi. org/10.2522/pti.20090035

38. Tiedemann AC, Sherrington C, Lord SR. Physical and psychological factors associated with stair negotiation performance in older people. J Gerontol A Biol Sci Med Sci. 2007;62(11):1259-65. https://doi. org/10.1093/gerona/62.11.1259

39. Ortega-Alonso A, Sipilä S, Kujala UM, Kaprio J, Rantanen T. Body fat and mobility are explained by common genetic and environmenta influences in older women. Obesity (Silver Spring). 2008;16(7):161621. https://doi.org/10.1038/oby.2008.235

40. Enright PL. The six-minute walk test. Respir Care. 2003;48(8):783-5.

41. Chetta A, Pisi G, Aiello M, Tzani P, Olivieri D. The walking capacity assessment in the respiratory patient. Respiration. 2009;77(4):361-7. https://doi.org/10.1159/000212781 